\section{ECONOMICS}

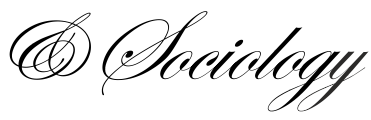

\title{
DETERMINANTS OF SOCIAL EXPENDITURES IN POST-SOCIALIST COUNTRIES
}

\author{
Hyejin Ko, \\ Korea Institute for Health and \\ Social Affairs \\ Sejongsi, South Korea \\ E-mailKobyejin@kihasa.re.kr \\ Kichae Min, \\ Korea National University of \\ Transportation \\ Chungcheongbukdo, South Korea \\ E-mail:minkichae@banmail.net \\ Received: January, 2019 \\ 1st Revision: February, 2019 \\ Accepted: May, 2019 \\ DOI: $10.14254 / 2071-$ \\ 789X.2019/12-2/15
}

\begin{abstract}
This study compares the development of the welfare state between Western capitalist countries and a selection of post-socialist countries of both Asia and Europe by examining the determinants of social expenditures in those. A pooled time-series, cross-sectional analysis with panel-corrected standard errors was conducted on the determinants of social expenditures in 21 post-socialist countries: Albania, Azerbaijan, Belarus, Bulgaria, Croatia, Czech, Estonia, Georgia, Hungary, Kazakhstan, Latvia, Lithuania, Moldova, Poland, Romania, Russia, Serbia, Slovakia, Slovenia, Ukraine, and Uzbekistan, using 2005 to 2017 data. It was found that, as in Western societies, democratic and welfare systems are more developed in post-socialist states than in welfare states. However, the effects of socialist heritage and globalization differ, depending on the degree of economic development of the country concerned. While in the OECD countries, globalization leads to the development of the welfare state, in non-OECD countries, socialist heritage is an enabling condition for development of the welfare state.
\end{abstract}

Keywords: post-socialist countries, social expenditure, welfare state, linear regression with panel-corrected standard errors.

\section{Introduction}

Conventional marxism has argued that welfare state cannot reconcile individual welfare and capital accumulation. After the emergence of welfare states following the World War II, neo-marxists partly modified their position, but they never changed their overall perspective that the pursuit of people's well-being cannot be realized under capitalism because of its affinity of capital. Although marxism continues to express skeptical views on the welfare state, the ongoing discussion about welfare state regime has already incorporated the study of socialism (Titmuss, 1974; Wilensky, 1975; Mishra, 1984). Study of socialist and post-socialist state welfare regimes is growing, although there have been a smaller number of these as compared to the studies of welfare capitalism. Research into the welfare regimes of socialist and post-socialist countries has produced contradictory results, but studies all have emphasized the distinguishing features in these countries from Western welfare states (Tracy \& Tracy, 1996; Adam, Kristan, \& Tomsic, 2009; Lendvai, 2008; Orenstein, 2008; Aspalter, Kim, \& Park, 2009). 
However, it remains unclear how post-socialist welfare states differ from Western welfare states. Few works so far have considered the development of the socialist or postsocialist welfare states in the context of comparative social policy research (International Labour Organization, 2010; Haggard \& Kaufman, 2008; Manning, 2004; Kuitto, 2016). While some comparative work did analyze welfare states in both Western and socialist countries during the Cold war (Wilensky, 1975; Kim, 1990), it is hard to find empirical work focusing on the development of the socialist welfare state after the post-socialist transformation. The primary interest is generally in Western welfare states, typically those that belong to the Organization for Economic Cooperation and Development (OECD). Thus, there is a need for consideration of transition countries, even though some of these, such as

Czech Republic, Hungary, Poland, Slovakia, Slovenia, and Estonia, are members of the OECD.

We here investigate the factors that have led to the development of post-socialist welfare state, including post-socialist Asian countries as well, in contrast with most of previous works, which have only focused on the Central and Eastern Europe. Using the existing theories that attempt to explain Western welfare state, we are also able to explain the development of the post-socialist welfare state; in particular, we can confirm what theory of the Western welfare state best explains the development of the post-socialist welfare state. In this way, we identify similarities and differences between Western welfare state and postsocialist welfare state so that to find common factors and explain their development in the post-socialist welfare states of both Asia and Europe.

\section{Determinants of Development of Western Welfare State}

What factors impact social spending in the post-socialist welfare state? During the socialist era, socialist countries of Europe were compared to capitalist countries (Wilensky, 1975; Kim, 1990), but it is difficult to find work on the factors that investigate social spending after transformation. This study uses existing studies of the development of the Western capitalist welfare states and applies it to the transition economies. Theories relating to the factors of the development of the welfare state are extensive, but this study focuses on major theories of the welfare state, structural functionalism, democracy theory, institutionalism, and globalization.

According to structural functionalism, social institutions are generated in response to changing needs that result from social change. For example, the increases in public social spending following the growth of social problems that came in the wake of the development of an industrial economy. Wilensky and Lebeaux (1965, p. 50-89) developed this perspective and suggested that public spending expands to encounter new social problems as family structures and demography change. Cutright (1965), Wilensky (1975), and Beblavy (2010) empirically demonstrated that economic development is a central main factor in the increases in social expenditure. Typically, the elderly population, according to structural functionalism, is identified as a significant factor to explain social spending in empirical research (Cutright, 1965; Wilensky and Lebeaux, 1965; Kim, 1990; Beblavy, 2010; Ahn and Lee, 2012; Hong, 2014). this is consistent with the idea that OECD countries have shifted toward a supply side orientation since the mid-1980s to encourage economic growth and support the employment rate (Starke, Wulfgramm, \& Obinger, 2016).

Subsequently, the maturity of democracy increased public welfare spending (Tilly, 2007). This factor is assessed by the pluralist and power resources theories, using separate perspectives on power dissipation. Pluralist theory focuses on the role of interest groups, which have equal opportunity to participate in the political decision-making process, while the latter focuses on the growth of the labor class, emphasizing the imbalance in power 
between it and the capitalist class. That is, the welfare state is considered to have developed in response to the pressure of interest groups that represent different political actors in the pluralist society (Dahl, 1958; Lindblom, 1977; Tsou, 1987; Beal, 2016). Power resources theory, for its part, considers that the development of the welfare state is the result of the growth of political power in the labor class in a democratic system, based on the principle of majority rule (Esping-Andersen, 1985).

Both theories argue that a mature democracy will expand social expenditures and come to develop the welfare state, although there are differences in the details. Specifically, the enhancement of political rights and the freedom of citizens should be positively correlated with social spending. However, the relationship between democracy and social spending has not been found to be constant in empirical studies because of differences in the period when developments have occurred and in the particular countries analyzed, as well as the variety of ways in which exogenous variables are controlled (Cutright, 1965; Habibi, 1994; Lindert, 1994; Lott, 1999; Przeworski et al., 2000; Brooks, 2005; Nooruddin \& Simmons, 2006b; Orenstein, 2008).

Next, institutionalism suggests that the historical context and pre-existing, established institutions in the country determine the current welfare system (Esping-Andersen, 1990, 1999). Studies in this vein adopt the perspective of historical institutionalism and use selected periods of social security as crucial variables for social expenditures (Cutright, 1965; Wilensky, 1975). The longer the period of social security, the greater the social security spending. Thus, the total time needed for the implementation of the system of social security or the timing of the introduction of the social security system is used as a variable in several institutionalist studies (Flora \& Alber, 1981; Kudrle \& Marmor, 1981; Hort \& Kuhnle, 2000; Saint-Arnaud \& Bernard, 2003; Pierson, 2007).

The socialist legacy, which also reflects the institutional conditions of transition economies, should also be considered in their contrast with capitalist countries. The relationship between the socialist legacy and social expenditures is unclear. Socialist and post-socialist countries have built universal social service systems, including education, healthcare, and housing services, with high amounts of social spending. The provision of universal childcare and educational services can also help bring about full employment by transferring the responsibility of childcare from the family to the state, pursuing the egalitarian ideals of communism (Aidukaite, 2004; Cerami, 2005, 2010; Haggard \& Kaufman, 2008; Inglot, 2008). Of course, socialist countries are in general able to increase their provision of welfare, thanks to the centralization of political power (Beal, 2016). However, social services are generally not provided on time due to chronic shortages (Deacon, 1992; Dixon \& Macarov, 2016). In socialist countries, because military needs are important, defense spending tends to take precedence over social welfare spending.

Finally, globalization theory has also been used to explain the development of the welfare state, and there is no consensus as yet regarding the relationship between globalization and the welfare state. The growth of globalized capital appears to imperil countries' social safety nets (Kim, 1990; Avelino, Brown \& Hunter, 2005; Rudra \& Haggard, 2005; Nooruddin \& Simmons, 2006). However, Pierson (2007, p. 207) argued that it is wrong to define the relationship between the welfare state and globalization in a uniform way because "globalization (the opening of a trade) is harmful to the welfare state." He supported Cameron (1978) and Katzenstein (1985), who concluded that the authority of Nordic countries has become even more necessary to the welfare state as globalization continues. Rodrik (1998) and Epifani and Gancia (2009) also argued that national governments tend to pursue social welfare systems and employment security to maintain domestic social cohesion, although the international economic integration has expanded to influence the development of the national level. 


\section{Methodological approach}

To investigate the determinants of social expenditures in post-socialist countries, we constructed cross-sectional time-series data for 21 countries: Albania, Azerbaijan, Belarus, Bulgaria, Croatia, Czech, Estonia, Georgia, Hungary, Kazakhstan, Latvia, Lithuania, Moldova, Poland, Romania, Russia, Serbia, Slovakia, Slovenia, Ukraine, and Uzbekistan, using 2005-2017 data. The causal factors for the development of welfare states can be summarized using estimates derived from the equation below:

$$
\begin{aligned}
E X P_{i t}= & \beta_{0}+\beta_{1} A G E_{i t-1}+\beta_{2} G D P_{i t-1}+\beta_{3} G R O_{i t-1}+\beta_{4} D E M_{i t-1}+\beta_{5} Y I S_{i t-1}+ \\
& +\beta_{6} S O P_{i}+\beta_{7} M I E_{i t-1}+\beta_{8} T R A_{t-1}+\beta_{9} F D I_{i t-1}+\beta_{10} H D I_{i t-1}
\end{aligned}
$$

The dependent variable here $\left(E X P_{i t}\right)$ is public welfare effect. After Wilensky (1975) defined the proportion of social security spending in gross national product as the social security effort (Wilensky 1975, p. 23), public social expenditures as a percentage of economic size (such as GNI or GDP) have been used as a variable to measure welfare effort (Bonoli, 1997, 2007; Ahn \& Lee, 2012; Hong, 2014). However, the use of aggregate public social expenditure as a proxy for welfare effort has been criticized because of its limitations in the investigation of the welfare dynamics of the post-1980s era, in contrast with studies of the expansion of social expenditures in the 1960s and 1970s (Marshall, 1965; Esping-Andersen, 1990; Kühner, 2007, 2015; Clasen \& Siegel, 2007).

Nevertheless, the reason for using social spending as a proxy for the development of the welfare state is its easy availability and comparability, despite the limitations of social spending (Jensen, 2011; Hong, 2014). Notably, total social expenditure can be useful for investigating the determinants of welfare spending if it can be used to develop comparability across countries and years (Hong, 2014). After the collapse of the Soviet Union, transition economies were quickly incorporated into capitalist society and produced similar statistics, as gathered by international organizations. Until the 1990s, data were less securely available, although it was possible to obtain data for comparative studies in these countries after 2000 . Social spending, as measured in this study, is likely more reliable than values created pursuant to national accounting standards.

Moreover, welfare generosity, an alternative measure developed by the Comparative Welfare Entitlements Dataset, also cannot precisely capture how many people are covered by benefits or what the outcomes of the social security system are. In particular, this factor may underestimate outcomes in post-socialist countries because of the lack of massive upheavals during the transition period (Kuitto, 2018), as well as the small number of post-socialist countries covered. Thus, the dependent variable in this study is welfare effort, defined as the proportion of social security spending as a percentage of GDP and extracted from the International Monetary Fund Government Finance Statistics, which includes old-age, disability, and survivors' pensions, allowances for illness, family needs, and maternity, unemployment benefits, and industrial accident insurance benefits. We considered ten factors to investigate the determinants of the development of post-socialist welfare states, based on the theory that describes them in Western countries. According to structural functionalism, with a focus on the homeostasis of the society, public social spending expands in response to the social problems that result from changes in the social structure when there are enough resources to meet the problem. Here, we considered people over age 65 as a percentage of the total population $\left(A G E_{i t-1}\right)$ to indicate changes in social structure and GDP per capita $\left(G D P_{i t-1}\right)$ and growth rate $\left(G R O_{i t-1)}\right.$ as resources. We obtained these data from the World Development Indicators, published by the World Bank. Moreover, because welfare demand varies according to the level of education and medical care in the given country, we 
additionally controlled the Human Development Index $\left(H D I_{i t-1}\right)$; data for this variable were extracted from the United Nations.

Second, we measured the maturity of the democracy $\left(D E M_{i t-1}\right)$, using the freedom index from Freedom House, which considers the degree of political rights and civil liberties, sorting countries into three statuses, "Free," "Partly Free," and "Not Free." We use the status value, with one representing "Not Free" and three representing "Free." Third, we incorporated the period of the social security system $\left(Y I S_{i t-1}\right)$, the period of socialism $\left(S O P_{i}\right)$, and the level of military spending $\left(M I E_{i t-1}\right)$ as proxies for historical institutionalism. $Y I S_{i t-1}$ measures by the sum of the social security system (old-age, disability, and survivors' pensions, allowance for illness, family and maternity benefits, unemployment benefits, and industrial accident insurance), with the 2017 data, based on information from the International Social Security Association. The starting point of the period of socialism $\left(S O P_{i}\right)$ was taken as the first year that the Communist Party established a revolutionary government there. $M I E_{i t-1}$ is the ratio of defense spending in terms of share of GDP. Fourth, trade volume $\left(T R A_{i t-1}\right)$ and foreign direct investment $\left(F D I_{i t-1}\right)$ were used as a variable to capture globalization. Trade volume (imports + exports) was measured as a percentage of GDP, and FDI is measured as the ratio of GDP to direct investment from foreign investors. Values for MIE, TRA, and FDI were taken from World Development Indicators published by the World Bank.

Furthermore, when we analyzed cross-sectional, time-series data, we needed to choose a method that incorporates heteroscedasticity, autocorrelation, contemporaneous correlation, and fixed effects. Here, using the statistical test of cross-sectional time-series data, shown in Table 1, we used panel-corrected standard errors proposed by Beck and Katz (1995) and included year dummy variables. Moreover, variables that have a unit root, such as GDP, $A G E, T R A$, and MIE, were transformed as difference stationary. Then, the dependent variable $(t)$ in all regression equations was entered for the corresponding value of 1 year after the independent variables $(t-1)$, taking time order as a causality materialization condition.

Table 1. Problems of cross-sectional time-series data and statistical treatment

\begin{tabular}{lcc}
\multicolumn{1}{c}{ Problems (test) } & $\begin{array}{c}\text { Test statistics } \\
\text { (F or chi-square) }\end{array}$ & Strategy \\
\hline Heteroscedasticity (modified Wald test) & $1677.56^{* * *}$ & Panel-corrected S.E. \\
\hline $\begin{array}{l}\text { Contemporaneous correlation (Pesaran } \\
\text { CD test) }\end{array}$ & $1.993^{*}$ & \\
\hline Serial Correlation (Wooldridge test) & 2.432 & Including year dummy \\
\hline Fixed Effect (countries) (Hausman test) & 10.67 & \\
\hline \multicolumn{1}{c}{ Time-fixed effects (Wald test) } & $2.78^{* *}$ &
\end{tabular}

\section{Conducting research and results}

Table 2 shows the results of the determinants of social spending in post-socialist countries, and Table 3 shows the results of further consideration of OECD status. Democracy theory, globalization, and historical institutionalism, which can explain the development of Western welfare states, show a significant ability to explain the development of post-socialist welfare states, as shown in Tables 2 and 3. 
INTERDISCIPLINARY APPROACH TO ECONOMICS AND SOCIOLOGY

Table 2. Determinants of social expenditure in post-socialist countries

\begin{tabular}{llll}
\hline & Coef. & S.E. & P value \\
\hline GRO & -0.196 & 0.062 & 0.002 \\
\hline GDP & 0.000 & 0.002 & 0.740 \\
\hline DEM & 2.637 & 0.400 & 0.000 \\
\hline AGE & 3.057 & 3.344 & 0.361 \\
\hline TRA & -0.005 & 0.029 & 0.859 \\
\hline FDI & -0.062 & 0.029 & 0.032 \\
\hline MIE & 0.249 & 0.366 & 0.497 \\
\hline YIS & 0.020 & 0.002 & 0.000 \\
\hline SOP & 0.069 & 0.024 & 0.004 \\
\hline HDI & -15.136 & 4.135 & 0.000 \\
\hline Constant & 8.901 & 2.316 & 0.000 \\
\hline $\mathrm{N}$ (group N) & $190(20)$ & & \\
\hline $\mathrm{R}^{2}$ & 0.657 & & 0.000 \\
\hline Wald chi & & &
\end{tabular}

Table 3. Determinants of social expenditure in post-socialist countries, grouped by OECD status

\begin{tabular}{|c|c|c|c|c|c|c|c|c|c|}
\hline & \multicolumn{3}{|c|}{ Model 1} & \multicolumn{3}{|c|}{ Model 2} & \multicolumn{3}{|c|}{ Model 3} \\
\hline & Coef. & S.E. & $\mathrm{P}$ value & Coef. & S.E. & $\mathrm{P}$ value & Coef. & S.E. & $\mathrm{P}$ value \\
\hline GRO & -0.230 & 0.066 & 0.001 & -0.195 & 0.056 & 0.001 & -0.356 & 0.113 & 0.002 \\
\hline GDP & 0.000 & 0.002 & 0.776 & -0.001 & 0.002 & 0.676 & -0.002 & 0.004 & 0.687 \\
\hline DEM & 2.678 & 0.409 & 0.000 & 2.718 & 0.345 & 0.000 & - & - & - \\
\hline $\mathrm{AGE}$ & 2.315 & 2.830 & 0.413 & 3.207 & 2.017 & 0.112 & 3.811 & 4.959 & 0.442 \\
\hline TRA & -0.011 & 0.030 & 0.709 & -0.018 & 0.039 & 0.640 & 0.079 & 0.045 & 0.075 \\
\hline FDI & -0.071 & 0.033 & 0.032 & -0.232 & 0.065 & 0.000 & 0.022 & 0.025 & 0.389 \\
\hline MIE & 0.237 & 0.419 & 0.571 & 0.253 & 0.435 & 0.560 & -2.337 & 2.227 & 0.294 \\
\hline YIS & 0.019 & 0.002 & 0.000 & 0.019 & 0.001 & 0.000 & -0.018 & 0.004 & 0.000 \\
\hline SOP & 0.091 & 0.024 & 0.000 & 0.090 & 0.016 & 0.000 & -0.052 & 0.063 & 0.415 \\
\hline HDI & -23.898 & 4.548 & 0.000 & -28.122 & 2.134 & 0.000 & -40.537 & 11.781 & 0.001 \\
\hline Constant & 2.000 & 0.374 & 0.000 & 19.415 & 4.142 & 0.000 & 58.641 & 8.497 & 0.000 \\
\hline OECD & 14.734 & 2.928 & 0.000 & & & & & & \\
\hline $\begin{array}{l}\mathrm{N} \\
\text { (groupN) }\end{array}$ & \multicolumn{3}{|c|}{$\begin{array}{l}190 \\
(20)\end{array}$} & \multicolumn{3}{|c|}{$\begin{array}{l}136 \\
(16)\end{array}$} & \multicolumn{3}{|c|}{$\begin{array}{l}47 \\
(6)\end{array}$} \\
\hline $\mathrm{R}^{2}$ & \multicolumn{3}{|c|}{0.6852} & \multicolumn{3}{|c|}{0.7298} & \multicolumn{3}{|c|}{0.4244} \\
\hline Wald chi ${ }^{2}$ & 4546 & 7.94 & 0.000 & & & 0.000 & & & 0.000 \\
\hline
\end{tabular}

Note: Model 1 is the same as Model 2, with the only difference that we control for the dummy variable indicating OECD status. Model 2 does not include OECD countries, and Model 3 only includes OECD countries; these are Czech Republic, Hungary, Poland, and Slovakia from 2005, Estonia and Slovenia from 2011, and Latvia from 2017.

The maturity of the democracy and the welfare system contributes to the promotion of public welfare in post-socialist countries at levels that are statistically significant. Although aging alone does not lead to any increase in public welfare effort at a statistically significant level, the maturity of the welfare system does lead to an increase in welfare expenditure, meaning that welfare expenditures have an inherent path-dependent nature (Esping-Andersen, 1990, 1999). Social security spending, especially social insurance spending, is paid as a right, based on the social security contributions paid by beneficiaries; thus, it is difficult to reduce such programs' spending, once they are introduced. Therefore, longer periods of social security cover more pensioners, thereby also resulting in increased social spending.

Interestingly, the progress of democracy has a positive effect on the expansion of public welfare efforts, as well as on the development of the welfare state, such that the 
government follows the public interest. If we regard democracy and socialism as conflicting political systems, these results are hard to understand. In the socialist system, political power can be concentrated, often leading to dictatorship. In fact, Tsou (1987) argued that the remnants of totalitarian political systems could be factors that impede the development of the welfare state, as in the case of China.

However, because socialist countries value equality, they generally establish universal social service systems. For example, in the constitution of the Soviet Union, social security was granted to each person as a social right by the state. Every citizen of the Soviet Union had the right to work; to vacations (or leaves); to social security in the case of old age, illness, or loss of working capacity; and to education and healthcare. These benefits were provided in kind rather than in cash to strengthen equality, described by Standing (1996) as "serviceheavy, transfer-light." The provision of universal childcare and educational services are also means of realizing full employment, by transferring the responsibility of childcare from the family to the state, pursuing egalitarian ideals. This result does not support studies that have found that universal entitlements in social security benefits under socialism can, when combined with democracy, expand social expenditure (Haggard \& Kaufman, 2008). However, as shown in Table 3, socialist experience does not have a significant impact on the promotion of welfare efforts when only OECD countries are targeted. Meanwhile, socialist experience cannot always be understood as a hinderance to public welfare.

Moreover, even though some such societies have sought to provide universal social services, the socialist states' planned economies could not afford deliver sufficient resources for their social policies due to the chronic "shortage economy" (Kornai, 1992; Rosser \& Rosser, 2018), which refers to the chronic budget deficits of such countries due to increases in financial support for state-owned companies and subsidies for necessities. Thus, the premise of social policy in socialist welfare focused on increasing production and assisting core workers rather than decreasing the income gap (Dixon \& Macarov, 2016). For this reason, YIS, which reflects the maturity of social insurance, has had a strong static impact on social spending.

Globalization also has variable impacts, depending on whether it occurs in an OECD state or not. Deepening globalization may negatively affect social spending. International organizations, such as the World Bank and IMF, have called for an adjustment of social security benefits, such as income replacement rates and benefit periods, as well as the restructuring of state-owned enterprises, the sale of state-run banks, and the privatization of social security schemes in post-socialist countries. Because post-socialist welfare states cannot avoid the pressures of a global economy, they must accept the welfare responsibilities of the private market and individuals. In response to this, over the past 20 years, post-socialist countries have generally completed a restructuring of state-owned enterprises. Specifically, as most countries have accepted restructuring based on financial aid, efforts to eliminate the institutional remnants of socialism have included significant modifications to social security systems, focusing mainly on pay cuts. In addition, as shown in the results of this analysis, the direct investment of foreign capital seems not to have positively affected welfare developments, even if it did contribute to the economic development of the post-socialist countries.

For OECD countries, globalization may have had a positive effect on social spending. The shift from a planned economy to an open-market economy has increased national income for post-socialist countries as they have transitioned. Moreover, the regulation of restructuring from international organizations has led to the introduction of a new social security system. During the socialist period, because of the intrinsic legitimacy of the socialist system, there was no unemployment or poverty policy developed in socialist countries. However, during the transition from socialism to capitalism, this legitimacy was lost. Thus, some governments of 
post-socialist countries attempted to introduce new social policies regarding unemployment, and the introduction of this new system may ultimately increase social spending to meet a global standard. Of course, resources to do so may be less available than in other countries.Conclusion

This study addressed the factors relating to the development of the welfare state in the post-socialist countries, both European and Asian. Incorporating theories that have been developed to explain the Western welfare state, we investigated whether such theories could be used to understand post-socialist countries. In summary, there are similarities between the determinants of the welfare state in post-socialist countries and the Western welfare state, including democracy theory and historical institutionalism. However, the post-socialist countries have unique features as well.

In these results, it is clear that the development of the post-socialist welfare state is similar to that of the Western welfare state. Above all, a more mature democracy is required for welfare state development. Historical institutionalism is a dominant candidate for explaining the post-socialist welfare state. The longer the social security period, the greater the public social expense of post-socialist countries; this factor also appears in the Western welfare state as well (Wilensky, 1975; Pierson, 2007).

The post-socialist welfare states have low levels of organized democratic forces, such as interest groups, the working class, and the left-leaning political parties that drove the development of the Western welfare state. Other actors, such as the working class, specialized interest groups, local governments, and non-governmental organizations, which develop and implement social policy in the place of the central government and party, are not strong (Getting, 1994, p. 181). Of course, democratic maturity makes a large difference in transition economies; some countries remain vestiges of totalitarian socialism, while others have achieved a Western democracy. For example, the Commonwealth of Independent States (CIS), including Russia, continue to exhibit a strong tendency toward authoritarianism, while EU member states, such as the Visegrád Group, appear to have developed a quite democratic political system. Post-socialist countries have encountered difficulties in development due to the remnants of the past totalitarian regime, and some have entered into a state of endless tension and conflict between the refuted forces and the liquidated forces of totalitarianism. However, we consider that the socialist heritage cannot be replaced by an authoritarian heritage. A more extended period of socialism tends to result in a higher level of social spending; its effects are particularly evident in the non-OECD post-socialist welfare state in which socialist remnants remain.

Last, globalization theory is also valid for explaining the development of the postsocialist welfare state. In particular, globalization increases social expenditures. Globalization is an essential factor in post-socialist transition economies because they are incorporated into the global economy through, for example, loans from international organizations, privatization of key industries, and trade facilitation with Western countries. The initial period of globalization created a lack of funding for social expenditures because of the privatization of the state-owned enterprises and collective farms by transnational corporations. The social spending caused by globalization can be attributed to privatization, capital outflow abroad, and the reduction of tax revenue, caused by the invasion of transnational capital and the involvement of international organizations.

However, transition economies over the past 20 years have generally completed a restructuring of state-owned enterprises. In an open economy, the enlargement of trade activates the domestic economy and increases tax revenue to ensure that welfare funds are expanded. The primary reason that globalization has a positive effect on social spending in the post-socialist welfare state is that the expansion of free trade through the World Bank, the International Monetary Fund, and the World Trade Organization have promoted economic 
development for the long term rather than trade within the socialism block-centered Council for Mutual Economic Assistance. That is, the transition from a closed, planned economy to an open-market economy is an opportunity to increase national income for the long run. The second reason is that the restructuring forced international organizations to introduce new social security systems. At the time of transition, almost all workers were working for stateowned enterprises, meaning that the selling of the state-owned enterprises created mass unemployment and a breakdown in the operation of production facilities. Full employment, which was considered to be the responsibility of the government, changed to underemployment, so workers had to find jobs in the market for themselves. The massive unemployment and poverty encountered as a result of this change posed a serious problem. At this time, systems of unemployment benefits and social assistance were introduced. In the socialist period, due to the justification of the socialist system, there was no policy for unemployment or poverty; however, since this justification was dismantled after the transition, it enabled the introduction of social policies for these challenges. The introduction of this new system to increase social spending was a convincing argument.

The main effort to remove the legacies of socialism was centered in restructuring the social security system reduce benefits. However, the relationship between globalization and social spending has not been found to be constant in previous empirical studies, and as seen from the results of this study, the impact of globalization appears to be more or less apparent in the post-socialist welfare state. In globalization, the expansion of trade networks with Western countries may have increased social welfare spending by encouraging economic growth in transition economies. In addition, the involvement of international organizations also led to new social security systems, such as unemployment insurance and public assistance. However, the progress of globalization also led to the development of welfare for relatively less developed among the post-socialist states.

This study showed what commonalities could explain the development of welfare states in post-socialist countries in Asia and Europe. However, due to the limitations of the data, this study could not fully account for the institutional, educational, welfare, or health system for each country. This is left as a task for future research.

\section{References}

Adam, F., Kristan, P., \& Tomšič, M. (2009). Varieties of capitalism in Eastern Europe (with special emphasis on Estonia and Slovenia). Communist and post-communist studies, 42(1), 65-81.

Aidukaite, J. (2011). Welfare Reforms and Socio-Economic Trends in the 10 New Eu Member States of Central and Eastern Europe. Communist and post-communist studies, 44(3), 211-219.

Ahn, S. H., \& Lee, S. S. (2012). Explaining Korean welfare state development with new empirical data and methods. Asian Social Work and Policy Review, 6, 67-85.

Aspalter, C., Kim., J., \& Park, S. (2009). Analysing the Welfare State in Poland, the Czech Republic, Hungary and Slovenia: An ideal-typical perspective. Social Policy \& Administration, 43(2), 170-185.

Avelino, G., Brown, D. S., \& Hunter, W. (2005). The effects of capital mobility, trade openness, and democracy on social spending in Latin America, 1980-1999. American Journal of Political Science, 49(3), 625-641.

Beal, A. L. (2016). Resources and Opportunity for Change: Democracy, Labor and the Welfare Effort in Latin America. The Journal of Social, Political, and Economic Studies, 41(2), 57-83. 
Beblavy, M. (2010). Comparative analysis of determinants and effects of social protection spending in the new EU member states. In P. Saunders., R. Sainsbury(eds). Social security, poverty and social exclusion in rich and poorer countries. Intersentia Publishing.

Beck, N., \& Katz. J. N. (1995). What to do (and not to do) with Time-Series Cross-Section Data. American political science review, 89(3), 634-647.

Bonoli, G. (1997). Classifying welfare states: a two-dimension approach. Journal of Social Policy, 26(3), 351-372.

Bonoli, G. (2007). Time matters: Postindustrialization, new social risks, and welfare state adaptation in advanced industrial democracies. Comparative Political Studies, 40(5), 495-520.

Brooks, S. (2005). Interdependent and domestic foundations of policy change: the diffusion of pension privatization around the world. International Studies Quarterly, 49(2), 273-294.

Cameron, D. R. (1978). The expansion of the public economy: a comparative analysis. American Political Science Review, 72(4), 1243-1261.

Cerami, A. (2005). Social Policy in Central and Eastern Europe: The Emergence of a New European Model of Solidarity? (Doctoral dissertation, Univ.-u. Forschungsbibliothek Erfurt/Gotha).

Cerami, A. (2010). The politics of social security reforms in the Czech Republic, Hungary, Poland and Slovakia. A long goodbye to Bismarck, 233-253.

Clasen, J., \& Siegel, N. A. (2007). Comparative welfare state analysis and the 'dependent variable problem'. Investigating welfare state change: The "dependent variable problem" in comparative analysis, 3-12.

Cutright, P. (1965). Political structure, economic development, and national social security programs. American Journal of Sociology, 70, 537-550.

Dahl, R. A. (1958). A Critique of the Ruling-Elite Model, American Political Science Review, $52,463-469$.

Deacon, B. (2000). Eastern European welfare states: the impact of the politics of globalization. Journal of European social policy, 10(2), 146-161.

Dixon, J., \& Macarov, D. (2016). Social welfare in socialist countries. Routledge.

Esping-Andersen, G. (1985). Power and distributional regimes. Politics and Society, 14, $223-$ 256.

Esping-Andersen, G. (1990). The three worlds of welfare capitalism. Princeton: Princeton University Press.

Esping-Andersen, G. (1999). Social foundations of post industrial economics. Oxford: Oxford University Press.

Flora, P., \& Alber, J. (1981). Modernization, democratization, and the development of welfare states in western Europe. In P. Flora \& A. J. Heidenheimer(eds). The Development of Welfare States in Europe and America. New Brunswick, New Brunswick, New Jersey: Transaction Books.

Getting, U. (1994). Destruction, adjustment, and innovation: social policy transformation in eastern and central europe. Journal of European Social Policy, 4(3), 181-200.

Habibi, N. (1994). Budgetary policy and political liberty: a cross-sectional analysis. World development, 22(4), 579-586.

Haggard, S., \& Kaufman, R. R. (2008). Development, democracy, and welfare states: Latin America. East Asia, and Eastern Europe. Princeton: Princeton University Press.

Hong, I. (2014). Trends and Determinants of Social Expenditure in K orea, J apan and T aiwan. Social Policy \& Administration, 48(6), 647-665.

Hort, S. O., \& Kuhnle, S. (2000). The coming of east and south-east Asian welfare states. Journal of European Social Policy, 10(2), 162-184. 
Inglot, T. (2008). Welfare States in East Central Europe, 1919-2004. Cambridge University Press.

International Labour Organization (2010). World Social Security Report 2010/11: Providing coverage in times of crisis and beyond. Geneva: ILO Publication.

Jensen, C. (2011). Less bad than its reputation: Social spending as a proxy for welfare effort in cross-national studies. Journal of Comparative Policy Analysis: Research and Practice, 13(3), 327-340.

Katzenstein, P.(1985). Small states in world markets. Ithaca: Cornell University Press.

Kim, T. S. (1990). Analysis of Determinants on Development of Social Welfare. Korean Journal of Social Welfare Studies, 2, 67-94.

Kornai, J. (1992). The socialist system: the political economy of communism. Princeton: Princeton University Press.

Marmor, T. R., \& Kudrle, R. T. (2017). The Development of Welfare States in North America. In Development of Welfare States in Europe and America (pp. 81-122). Routledge.

Kuitto, K. (2016). Post-communist welfare states in european context: Patterns of welfare policies in Central and Eastern Europe. Edward Elgar Publishing.

Kuitto, K. (2018). Measuring welfare entitlement generosity in transitional welfare states: The case of post-communist countries in central and Eastern Europe. Social Indicators Research, 136(1), 203-224.

Kühner, S. (2007). Country-level comparisons of welfare state change matter: Another facet of the dependent variable problem within the comparative analysis of the welfare state?. Journal of European Social Policy, 17, 1, 5-18.

Kühner, S. (2015). What if we waited a little longer? The dependent variable problem within the comparative analysis of the welfare state revisited. Social Policy Review, 27, 199224.

Lendvai, N. (2008). EU Integration and the Transformation of Post-communist Welfare: Traversing a 'Quantum Leap'?. Social Policy \& Administration, 42(5), 504-523.

Lindblom, C. D. (1977). Markets and Politics. New York: Basic Books.

Lindert, P. H. (1994). The rise of social spending, 1880-1930. Explorations in Economic History, 31(1), 1-36.

Lott, J. R. (1999). Public schooling, indoctrination, and totalitarianism. Journal of Political Economy, 107(6), 127-157.

Manning, N. (2004). Diversity and change in pre-accession central and eastern Europe since 1989. Journal of European Social Policy, 14(3), 211-232.

Marshall, T. H. (1965). Class, Citizenship, and Social Development. New York: Doubleday.

Mishra, R. (1984). The welfare state in crisis: social thought and social change. Wheatsheaf Books.

Nooruddin, I., \& Simmons, J. W. (2006). The politics of hard choices: IMF programs and government spending. International Organization, 60(4), 1001-1033.

Orenstein, M. A. (2008). Postcommunist welfare states. Journal of Democracy, 19(4), 80-94.

Pierson, C. (2007). Beyond the welfare state. Cambridge: Polity Press.

Przeworski, A., Alvarez, M. A., Cheibub, J. A., \& Limongi, F. (2000). Democracy and development: political institutions and well-being in the world, 1950-1990. New York: Cambridge University Press.

Rodrik, D. (1998). Why do more open economies have bigger governments?. Journal of political economy, 106(5), 997-1032.

Rosser Jr, J. B., \& Rosser, M. V. (2018). Comparative economics in a transforming world economy. Mit Press. 
Rudra, N., \& Haggard, S. (2005). Globalization, democracy and effective social spending in the developing world. Comparative Political Studies, 38(9), 1-35.

Saint-Arnaud, S., \& Bernard, P. (2003). Convergence or resilience? a hierarchical cluster analysis of the welfare regimes in advanced countries. Current Sociology, 51(5), 499527.

Standing, G. (1996). Social protection in Central and Eastern Europe: a tale of slipping anchors and torn safety nets. Welfare states in transition: National adaptations in global economies, 225-255.

Starke, P., Wulfgramm, M., \& Obinger, H. (2016). Welfare state transformation across OECD countries: Supply side orientation, individualized outcome risks and dualization. In Welfare state transformations and inequality in OECD countries (pp. 19-40). Palgrave Macmillan, London.

Tilly, C. (2007). Democracy, Cambridge: Cambridge University Press.

Titmuss, R. (1974). Social policy, London. Allen \&Unwin.

Tracy, M. A., \& Tracy, M. B. (1996). The impact of market economy transition on social security and social welfare in Poland. Journal of Sociology and Social Welfare, 23, 23.

Tsou, T. (1987). Marxism, the Leninist party, the masses, and the citizens in the rebuilding of the Chinese state. In S. R. Schram(ed). Foundation and limits of state power in China. London: University of London.

Wilensky, H. (1975). The welfare state and equality: structural and ideological roots of public expenditures. Berkeley: University of California Press.

Wilensky, H., \& Lebeaux, C. N. (1965). Industrial society and social welfare. New York: Russell Sage Foundation. 